\title{
The Cytochemical Study of Oxygen-Dependent and Oxygen-Independent Components of Bactericidal Activity of Dog' Peripheral Blood Leukocytes
}

\author{
Alexander Bokarev, Anatoliy Stekolnikov, Anatoliy Kudryashov, Marina Narusbaeva and Anastasia \\ Minina
}

Saint-Petersburg state university of veterinary medicine, Saint Petersburg, Russia

*Corresponding author: segwan@rambler.ru

Article History: 21-350 Received: 07-Jul-21 1 Revised: 25-Jul-21
ABSTRA C T
The scientific literature does not discuss how the oxygen-dependent and oxygen-independent mechanisms of
bactericidal activity of peripheral blood phagocytes relate to each other. For example, does oxygen-dependent and
oxygen-independent bactericidal mechanisms act by themselves and independently? Or do they interact, potentiating
each other's action? This work aimed to study the cooperation (clarification of the participation) of oxygen-dependent
and oxygen-independent bactericidal systems of peripheral dog' blood neutrophils in the phagocytosis process. The
mechanism of oxygen-dependent bactericidal activity of neutrophils was visualized in the NBT test. Study of the
oxygen-independent bactericidal activity mechanism of neutrophils flowing through bactericidal proteins by
Pigarevsky. Cytological preparations had been examining under immersion objective. Obtained results confirmed the
well-known fact that a certain amount of peripheral blood granulocytes contains substances responsible for oxygen-
dependent and bactericidal activity. These two mechanisms of bactericidal activity, responses different cells. In
phagocytosis, bactericidal substances gradually accumulated around the phagocytosed material and, after a while,
completely impregnated it. In addition, particles phagocytosed by leukocytes containing cationic proteins were also
gradually enveloped by the latter. However, in the research process, it was not established that these proteins penetrate
deeply into phagocytosed particles. In the studied preparations, several such variants of the interposition of NBT-
positive phagocytes and phagocytes containing cationic proteins are visualized, suggesting that these cells can interact
in phagocytosis. It was found that different granulocytic cells have oxygen-dependent and oxygen-independent
bactericidal activity. Also, bactericidal activity is exposed to bactericidal action by leukocytes, responsible for the
oxygen-independent activity.

Key words: Phagocytosis, Superoxide anion, Cationic proteins, Granulocytes, Cytoplasm, NBT-Test.

\section{INTRODUCTION}

Despite the advances in veterinary surgery, surgical infection remains extremely relevant since its prevention and treatment in animals do not always provide a positive result. And in some cases, it leads to severe complications, including sepsis (Morrison et al. 1995). Regardless of the location, the first barrier to surgical infection is always the mechanism of resistance (Rechenberg et al. 2016). A priori, it can be argued that the more effective these mechanisms are, the less likely it is that the body's contact with microorganisms will lead to severe purulent complications (Lu et al. 2016). To increase the resistance of animals, doctors use various, both specific and nonspecific biological stimulants (Couturier et al. 2011). However, the effectiveness of such stimuli still leaves much to be desired.
Therefore, it should be recognized that in most cases, no doctor will entrust the life of his patient with a purulent infection exclusively to stimulants of resistance or immunity and will resort to antibiotic therapy.

The very idea of preventing and/or treating infectious surgical diseases by stimulating resistance mechanisms is scientifically substantiated (Ulrich et al. 2020). However, at this stage, resistance mechanisms have not yet been studied to such an extent as to create effective drugs of this group that can completely replace antibiotics (Chammas and Hagiwara 1998). And this means that the scientific search in this direction should: be continuing.

Phagocytosis is one of the main components of the complex resistance mechanism (Uribe-Querol and Rosales 2020). If consider phagocytosis as a way to fight infection, then the following main stages can note 1) endocytosis, i.e.,

Cite This Article as: Bokarev A, Stekolnikov A, Kudryashov A, Narusbaeva M, and Minina A, 2022. The cytochemical study of oxygen-dependent and oxygen-independent components of bactericidal activity of dog' peripheral blood leukocytes. International Journal of Veterinary Science 11(1): 104-109. https://doi.org/10.47278/journal.ijvs/2021.085 
the absorption of an infectious agent; 2) inactivation of the infectious agent; 3 ) digestion of the infectious agent and 4) exocytosis, i.e., removal of the products of inactivation and fermentation of the infectious agent from the cell. In this sequence of events, perhaps the most important is the inactivation of the carrier of the infection. As it is known, phagocytes, in particular neutrophils, have two: oxygendependent and oxygen-independent, bactericidal mechanisms (Forrest and Warrender 2004). The first is associated with the oxidation of glucose in the glucosemonophosphate shunt (GMPS) with the formation of various oxidants with bactericidal properties (Miceli et al. 1990). The second is associated with lysozyme, cationic proteins, lactoferrin, proteolytic enzymes, lipase ( $\mathrm{Li}$ et al. 2020). In routine semi-quantitative screening tests, morphologically reflecting the patient's resistance level, either oxygen-dependent bactericidal activity is usually tested in the NBT test. In this test, live neutrophils are incubated in the presence of colorless nitro-blue tetrazolium absorb the latter and, by reaction with oxidants, convert it into dark blue formazan (Haghniaz et al. 2021). The number of formazan-positive cells and the amount of formazan formed in one cell are the evaluation criteria. Or cytochemical visualize cationic proteins, the activity of which is not associated with oxygen, but which, by binding to the surface membrane of bacteria and changing their permeability (Kolesnik et al. 2019).

The available scientific literature does not discuss how these two different mechanisms of bactericidal activity of peripheral blood phagocytes relate to each other. For example, do oxygen-dependent, and oxygen-independent bactericidal mechanisms act independently and dependently? Or do they interact, potentiating each other's action? This work aimed to study the cooperation (clarification of the participation) of oxygen-dependent and oxygen-independent bactericidal systems of peripheral blood neutrophils in dogs in the process of phagocytosis.

\section{MATERIALS AND METHODS}

\section{Ethical Statement}

This research was conducted following ethical standards for using animals for scientific purposes, referred to Federal Law of 24.04.1995 N 52-FL (as amended on 08.12.2020) "On the animal world". The neutrophil source was peripheral dog' blood of healthy mongrel animals 3-7 years old. The blood had been taking with heparin from the saphenous vein of the forearm (Minutes No. 264 dated 04/05/2021).

\section{The NBT Test}

The oxygen-dependent bactericidal activity mechanism of neutrophils had been diagnosing by the NBT test (reaction with nitro blue tetrazolium to superoxide anion) (Gordon et al. 1975). The Spontaneous NBT test was performing next way: To heparinized blood $(0.25 \mathrm{~mL})$ was adding $0.25 \mathrm{~mL}$ of phosphate-buffered saline ( $\mathrm{pH} 7.4)$ and $0.5 \mathrm{~mL}$ of $0.2 \%$ nitroblue tetrazolium solution (Sigma) onto phosphate-buffered saline. The stimulated NBT test was doing so: To $0.25 \mathrm{~mL}$ of heparinized blood was adding $0.15 \mathrm{~mL}$ of phosphate-buffered saline ( $\mathrm{pH} 7.4)$, and $0.1 \mathrm{~mL}$ of pyrogenal ("Medgamal" Russia (100mg/mL)) and $0.5 \mathrm{~mL}$ of $0.2 \%$ nitroblue tetrazolium solution (Sigma) onto phosphate-buffered saline.
The neutrophils' phagocytic reaction simultaneously with NBT test was doing such: To $0.25 \mathrm{~mL}$. of heparinized blood was adding $0.25 \mathrm{~mL}$ of baker's yeast suspension onto phosphate-buffered saline $(\mathrm{pH} 7.4)$ and $0.5 \mathrm{~mL}$ of $0.2 \%$ nitroblue tetrazolium solution (Sigma) in phosphatebuffered saline. Baker's yeast had been inactivating by boiling, then washed three times with phosphate-buffered saline. This baker's yeast suspension contained 50 thousand cells in $1.0 \mu \mathrm{L}$, with a particle ratio of phagocyte/ phagocytirhemic approximately $1 / 4$. All reactions were in Eppendorf tubes by $37^{\circ} \mathrm{C}$ for $40 \mathrm{~min}$. The fixation of cytological preparations was by methanol for $10 \mathrm{~min}$.

The study of the mechanism of oxygen-independent bactericidal activity of neutrophils was carried out by staining for cationic proteins (Pigarevskiǔ et al. 1986) for 30min (painting with a $0.1 \%$ solution of strong green in an aqueous $12.5 \%$ solution of methyl alcohol). Nuclei staining was carried out in a $1 \%$ aqueous solution of sofranin for 1520min. The prepared preparations composed of 1) native blood, 2) spontaneous NBT test, 3) induced NBT test and 4) phagocytic reaction + NBT-test (only coloring with sofranin) The following drugs/cells were obtained for the study:

1. Non-activated leukocytes stained for cationic proteins.

2. Non-activated leukocytes stained in the NBT test.

3. Non-activated leukocytes stained in the NBT-test and for cationic proteins.

4. Activated leukocytes stained for cationic proteins.

5. Activated leukocytes stained in the NBT test.

6. Activated leukocytes stained in the NBT test and for cationic proteins.

7. Leukocytes phagocytic yeast cells stained for cationic proteins.

8. Leukocytes phagocytic yeast cells stained in the NBT test.

9. Leukocytes phagocytic yeast cells stained in the NBTtest and for cationic proteins.

Cytological preparations were examined under a×100 immersion objective on a Lumam P-8 microscope equipped with a 5-megapixel digital camera. In addition, visualization and fixation of images from a digital camera were carried out on a personal computer using the ScopeTecScopt Photo program version 3.0.12.489.

\section{Statistical Analysis}

The variational-statistical processing of the research results was carried out on IBMPC/AT and "Pentium IV" in Windows 2000, using the data analysis package in the program "Excel Windows Office XP" and "Statistika 6.0" (Statsoft, USA) with the calculation of the arithmetic Mean \pm SE. In the statistical analysis of the data obtained, the student's t-test was used for independent samples, while the differences were considered significant at $\mathrm{P}<0.05$. All anatomical and histological terms according to Constantinescu and Constantinescu (2013) and International histological nomenclature.

\section{RESULTS}

After a spontaneous NBT test (incubation with nitro blue tetrazolium in the absence of activators), a slightly dark blue granularity was visualized in the cytoplasm of some leukocytes (Fig. 1-1-a). According to Pigarevsky, green granularity was visualized in the cytoplasm of some 
leukocytes (Fig. 1-3-b). In the case when, after the spontaneous NBT test, cytological preparations were additionally stained by (Pigarevskiǐ et al. 1986), cells containing only dark blue cytoplasmic granularity and cells containing only green granules in the cytoplasm were visualized separately.

Cells that simultaneously contain both dark blue and green granularity were not identified. If pyrogen was added to the incubation medium during the NBT test, the granularity in the corresponding cells' cytoplasm increased (Fig. 1-2-a). At the same time, both the quantitative and qualitative characteristics of granularity in cells stained for cationic proteins remained unchanged (Fig. 1-4-b). The color pattern of granulocytes in the NBT test, in the process of phagocytosis of baker's yeast cells, changed in such a way that at first, the formazan granules were localized in the cytoplasm of cells intact from phagocytosed yeast (Fig. 2-1-a, e). Then the number of formazan granules increased significantly, and they surrounded the phagocytosed yeast cells (Fig. 2-2-a, e). In the final version, individual formazan granules were not visualized in the cytoplasm of leukocytes, and phagocytosed yeast cells themselves were diffusely stained dark blue (Fig. 2-3-e-1).

A similar, but not analogous, the picture was when leukocytes were stained in the process of phagocytosis of yeast cells for cationic proteins by Pigarevsky. Initially, granules containing cationic proteins were localized in the cytoplasm of cells, intact from phagocytosed yeast (Fig. 2$4-b, e)$. Then they began to surround the phagocytosed yeast cells (Fig. 2-5-b, e). Finally, and in the final version, the granules completely enveloped the phagocytosed material, at the same time, for the most part, remaining on its periphery (Fig. 2-6-e).

With light-optical microscopy of preparations prepared from a suspension of peripheral blood leukocytes, which were in the process of phagocytosis of yeast cells, variants of close contact of two phagocytes were visualized, one of which was stained in the NBT test, and the second - for cationic proteins by Pigarevsky (Fig. 3).

In the studied preparations, three morphological variants of granulocyte contact were identified. The first option - granulocytes were located side by side. One of them had phagocytosed material and granules stained for cationic proteins. Another granulocyte had phagocytosed material stained with nitro blue tetrazolium (Fig. 3-1). The second option - the granules stained for cationic proteins not only surrounded the phagocytosed yeast in the corresponding granulocyte but also closely contacted the yeast cells that were phagocytosed by the granulocyte stained in the NBT test (Fig. 3-2). The third variant - yeast cells diffusely stained with nitroblue tetrazolium- were visualized, not in NBT positive phagocytes, but in phagocytes with cationic proteins in the cytoplasm (Fig. 3$3,4)$. Moreover, granules of cationic proteins accumulated around yeast cells stained with nitro blue tetrazolium.

Additionally, it should be noted that in the investigated cytological preparations, two variants of yeast cells outside of phagocytes were identified. Some of them were stained red with safranin (Fig. 4-2). At the same time, others had a dark blue coloration by analogy with yeast cells found inside NBT-positive phagocytes (Fig. 4-1). Probably, the former was not yet phagocytosed yeast cells. In contrast, the latter were yeast cells phagocytosed with NBT-positive leukocytes and released outside the phagocyte through exocytosis.

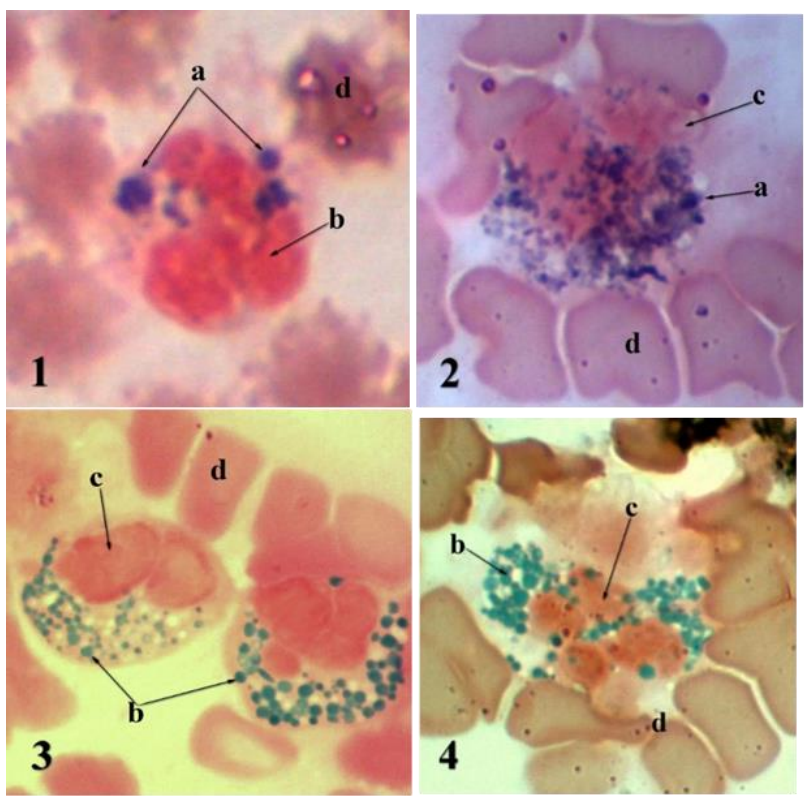

Fig. 1: Cytochemical visualization of bactericidal activity mechanisms in dogs' peripheral blood neutrophils (optical zoom $\times 1600$ ). 1 and 2 are oxygen-dependent mechanism visualization in the test with reduce nitroblue tetrazolium (NBT test). 3 and 4 are oxygen-independent mechanism visualization when staining for cationic proteins. 1 and 3 are spontaneous activity. 2 and 4 are stimulated activity. a: formazan granules in NBT positive phagocytes; $b$ : lysosomes containing cationic proteins; c: cell nuclei stained with sofranin and d: erythrocytes.

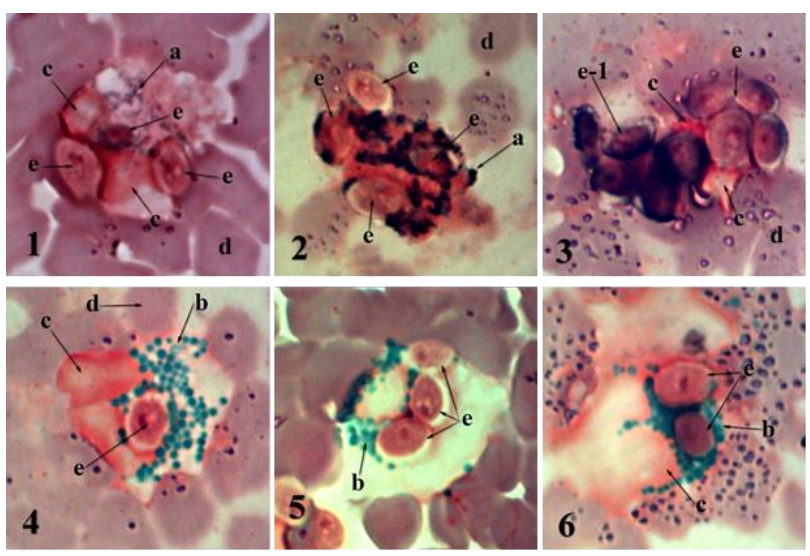

Fig. 2: Cytochemical visualization of the mechanisms of bactericidal activity in peripheral blood neutrophils of dogs in the process of phagocytosis of baker's shiver bodies (optical zoom $\times 1600$ ). 1, 2, and 3: Successive changes in the visualization of the oxygen-dependent mechanism in the test with the reduction of nitroblue tetrazolium (NBT test). 4, 5, and 6: Successive changes in the visualization of the oxygen-independent mechanism when staining for cationic proteins. a: formazan granules in NBT positive phagocytes; b: lysosomes containing cationic proteins; c: cell nuclei stained with sofranin; d: erythrocytes; e: unchanged or slightly altered phagocytosed yeast fungi; and e-1: phagocytosed yeast fungi intensely stained with formazan. 

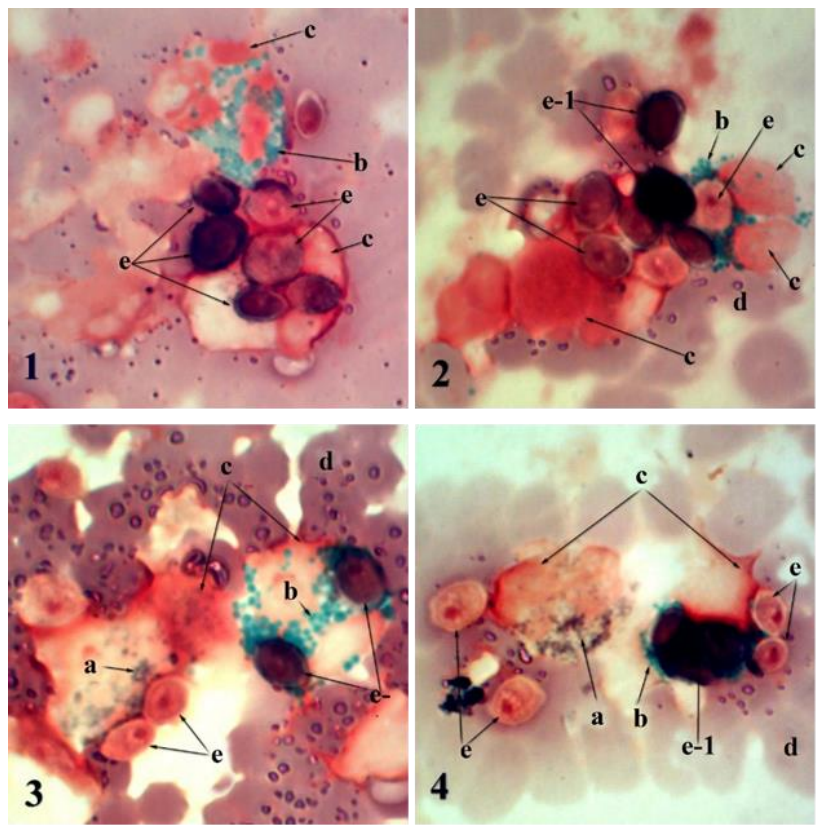

Fig. 3: Variants of cooperation of NBT+and CTB+leukocytes of peripheral blood of dogs in the process of phagocytosis of yeast cells. (Optical zoom $\times 1600)$. 1) CTB+phagocyte (above) and NBT+phagocyte (below) is located side by side; 2) $\mathrm{CTB}+$ phagocyte (right) and NBT+phagocyte (left) are in close contact, and granules containing cationic proteins begin to cover yeast cells stained with nitro blue tetrazolium, and 3 and 4) in $\mathrm{CTB}+$ phagocyte (right), granules of cationic proteins surround yeast cells strongly stained with nitro blue tetrazolium. NBT+phagocyte (left) has a small number of reduced tetrazolium granules and phagocytosed yeast cells not stained with tetrazolium. a: formazan granules in NBT positive phagocytes, $b$ : lysosomes containing cationic proteins, c: cell nuclei stained with sofranin, d: erythrocytes, e: unchanged or slightly altered phagocytosed yeast fungi, and e-1: phagocytosed yeast fungi intensely stained with formazan.

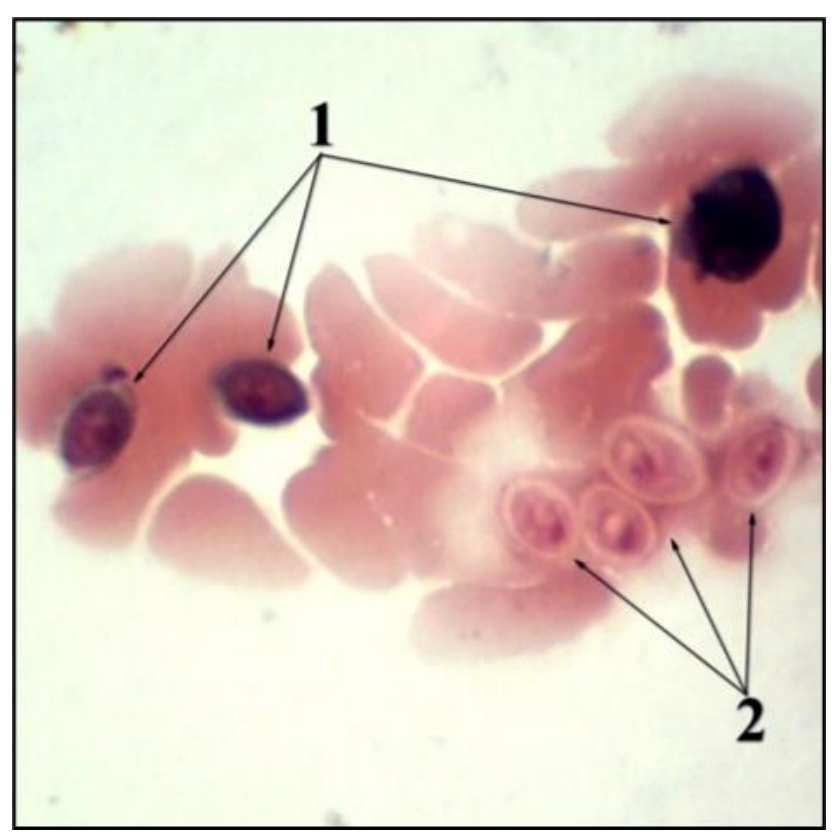

Fig. 4: Fungal cells are located extracellularly. (Optical zoom $\times 1600)$. 1: fungal cells stained with reduced nitro blue tetrazolium and 2: fungal cells not stained with reduced nitro blue tetrazolium.

\section{DISCUSSION}

The study results correspond to the well-known fact that a certain number of peripheral blood granulocytes contains substances responsible for oxygen-dependent (Smirnova et al. 2018) (spontaneous NBT test (Fig. 1-1) and oxygen-independent (Tovmasyan et al. 2020) (cationic proteins (Fig. 1-3) bactericidal activity (Tohyama et al. 2019). Studies have shown that different cells are responsible for these two mechanisms of bactericidal activity. If soluble activators are present in the culture medium simulating the in vitro process of phagocytosis, then the number of leukocytes that react in the NBT test increases (Nowicka et al. 2018). In addition, the individual oxygen-dependent bactericidal activity of individual cells also increases (Fig. 1-2). At the same time, the number of cells containing cationic proteins does not increase, just as the number of cationic proteins in their cytoplasm does not increase (Fig. 1-4).

In the process of phagocytosis, bactericidal substances, which were visualized in the NBT test as substances converting colorless nitro blue tetrazolium into dark blue formazan, gradually accumulated around the phagocytosed material (Fig. 2-2) and, after a while, completely impregnated it (Fig. 2-3). Furthermore, the particles phagocytosed by leukocytes containing cationic proteins were also gradually enveloped by the latter (Fig. $2-4,5,6)$. However, it was not established during the study that these proteins penetrate deeply into phagocytosed particles (Table 1).

In the studied preparations, the most exciting fact is that many such variants of the interposition of NBTpositive phagocytes and phagocytes containing cationic proteins are visualized, suggesting that these cells can interact during phagocytosis (Barillet et al. 2019). If assume that such cooperation has a certain vector of development, then it most likely looks like this (Fattori et al. 2020). Initially, the NBT-positive phagocyte and the phagocyte containing cationic proteins converge on their cell membranes (Fig. 3-1). Then, the phagocytosed material, treated with substances of the oxygen-dependent bactericidal mechanism, comes into contact with the cationic proteins of another phagocyte (Fig. 3-2) (Abakumova et al. 2016). And at the final stage, the cationic proteins of the second phagocyte surround the particles phagocytosed and treated with oxidants by the first phagocyte (Fig. 3-3, 4) (Mandala et al. 2020).

However, the question arises, how can phagocytosed particles of NBT-positive leukocyte contact with cationic proteins of another leukocyte? Theoretically, these two phagocytes should be separated by two plasma membranes (Yousef et al. 2021). Then, they either merge into one binuclear cell by analogy with macrophages (Iqbal et al. 2015). Or particles phagocytosed by NBT-positive leukocytes and treated with bactericidal oxidants are removed from it by exocytosis. And after exocytosis, the particles are re-phagocytosed by leukocytes containing cationic proteins (Vandendriessche et al. 2021). The latter option is indirectly confirmed because the studied preparations contained many yeast cells located extracellularly and stained with formazan (Fig. 4-1). This indicates that they have been inside NBT-positive phagocytes and reacted with substances of the oxygendependent bactericidal mechanism. 
Table 1: Quantitative, qualitative, and distribution characteristics of oxygen-dependent and oxygen-independent mechanisms of bactericidal activity of canine peripheral blood phagocytes

\begin{tabular}{|c|c|c|c|c|c|c|}
\hline \multirow{3}{*}{$\begin{array}{l}\text { Phagocytosis } \\
\text { stages }\end{array}$} & \multicolumn{6}{|c|}{ Cytochemical visualization of the } \\
\hline & \multicolumn{2}{|c|}{$\begin{array}{l}\text { Percentage of phagocytes } \\
\text { containing bactericidal } \\
\text { substances }\end{array}$} & \multicolumn{2}{|c|}{$\begin{array}{l}\text { Quantitative changes in bactericidal } \\
\text { substances in the cytoplasm of } \\
\text { phagocytes }\end{array}$} & \multicolumn{2}{|c|}{$\begin{array}{l}\text { Localization of bactericidal substances in } \\
\text { phagocytes relative to phagocytosed } \\
\text { particles }\end{array}$} \\
\hline & $\mathrm{A}^{*}$ & $\mathrm{~B} * *$ & $\mathrm{~A}^{*}$ & $\mathrm{~B} * *$ & $\mathrm{~A}^{*}$ & $\mathrm{~B}^{* *}$ \\
\hline $\begin{array}{l}1 \text { Before } \\
\text { phagocytosis }\end{array}$ & $5-12$ & $12-23$ & $=* * *$ & $=* * *$ & In the cytoplasm & In the cytoplasm \\
\hline $\begin{array}{l}2 \text { At the } \\
\text { beginning of } \\
\text { phagocytosis }\end{array}$ & $35-45$ & $12-23$ & $>* * * *$ & $=$ & $\begin{array}{l}\text { At the periphery of } \\
\text { phagocytosed } \\
\text { particles }\end{array}$ & $\begin{array}{l}\text { Migrate side of } \\
\text { phagocytosed particles }\end{array}$ \\
\hline $\begin{array}{l}3 \text { In the active } \\
\text { phase of } \\
\text { phagocytosis }\end{array}$ & $60-85$ & $12-23$ & $>>* * * * *$ & $=$ & $\begin{array}{l}\text { On the periphery } \\
\text { and inside } \\
\text { phagocytosed } \\
\text { particles }\end{array}$ & $\begin{array}{l}\text { Densely around the } \\
\text { periphery of } \\
\text { phagocytosed particles }\end{array}$ \\
\hline
\end{tabular}

$\mathrm{A}=$ Oxygen Dependent*, $\mathrm{B}=$ Oxygen independent**. $*=$ Detected visually in the NBT test. $* *=$ Detected visually when staining for cationic proteins. ${ }^{* * *}=$ Content in non-stimulated cells. $* * * *=$ The number of cells in the cytoplasm increases. $* * * * *=$ The number of cells in the cytoplasm increases significantly.

\section{Conclusion}

In an inactivated state, the granulocytes of the peripheral blood of dogs have either oxygen-dependent bactericidal activity (oxidants) or oxygen-independent bactericidal activity (cationic proteins). In activated neutrophils with oxygen-dependent bactericidal activity (oxidants), the quantitative parameters of the latter increase. At the same time, the quantitative parameters of the components of oxygen-independent bactericidal activity (cationic proteins) in the corresponding granulocytes remain unchanged. Phagocytes responsible for the oxygen-dependent mechanism of bactericidal activity interact with phagocytes responsible for the oxygen-independent mechanism of bactericidal activity. In this case, phagocytosed particles treated with bacteriotoxic oxidants in one phagocyte are additionally surrounded and treated with cationic proteins in another.

\section{Author's Contribution}

AS conceived of the presented idea and supervised the project. $\mathrm{AB}$ developed the theory and performed the computations. AK verified the analytical methods. AM carried out the experiment. MN wrote the manuscript with support from $\mathrm{AM}, \mathrm{AK}$ and $\mathrm{AB}$.

\section{REFERENCES}

Abakumova TV, Antoneeva II, Gening TP, Dolgova DR and Gening SO, 2016. Phenotype of peripheral blood neutrophils in the initial stage of endometrial cancer. Tsitologiia 58: 2329.

Barillet S, Fattal E, Mura S, Tsapis N, Pallardy M, Hillaireau H and Kerdine-Römer S, 2019. Immunotoxicity of poly (lacticco-glycolic acid) nanoparticles: influence of surface properties on dendritic cell activation. Nanotoxicology 13: 606-622. https://doi.org/10.1080/17435390.2018.1564078

Chammas PPC and Hagiwara MK, 1998. Evaluation of neutrophilic function (chemotaxis, phagocytosis and microbicidal activity) in healthy dogs and in dogs suffering from recurrent deep pyoderma. Veterinary Immunology and Immunopathology 64: 123-131. https://doi.org/10.1016/ $\underline{\text { S0165-2427(98)00130-5 }}$

Couturier K, Qin B, Batandier C, Awada M, Hininger-Favier I, Canini F, Leverve X, Roussel AM and Anderson RA, 2011. Cinnamon increases liver glycogen in an animal model of insulin resistance. Metabolism: Clinical and Experimental
60: 1590-1597. https://doi.org/10.1016/j.metabol.2011 $\underline{03.016}$

Fattori V, Rasquel-Oliveira FS, Artero NA, Ferraz CR, Borghi SM, Casagrande R and Verri WA, 2020. Diosmin Treats Lipopolysaccharide-induced inflammatory pain and peritonitis by blocking NF- $\mathrm{B}$ activation in mice. Journal of Natural Products 83: 1018-1026. https://doi.org/10.1021/ acs.jnatprod.9b00887

Forrest S and Warrender C, 2004. Modeling intercellular interactions in the peripheral immune system. Simantic Scholar. https://www.semanticscholar.org/paper/Modelingintercellular-interactions-in-the-immune-Forrest-Warrender Ic842105348e885ba468b682b1f98a153d8d9651d

Gordon PA, Stuart J and Lee TR, 1975. The cytocentrifuge NBT test. Journal of Clinical Pathology 28: 674-679. https://doi.org/10.1136/jcp.28.8.674

Haghniaz R, Rabbani A, Vajhadin F, Khan T, Kousar R, Khan AR, Montazerian H, Iqbal J, Libanori A, Kim HJ and Wahid F, 2021. Anti-bacterial and wound healing-promoting effects of zinc ferrite nanoparticles. Journal of Nanobiotechnology 19: 38. https://doi.org/10.1186/s12951-021-00776-w

Iqbal MA, Umar MI, Haque RA, Khadeer Ahamed MB, Asmawi MZ, Bin AM and Majid SA, 2015. Macrophage and colon tumor cells as targets for a binuclear silver(I) N-heterocyclic carbene complex, an anti-inflammatory and apoptosis mediator. Journal of Inorganic Biochemistry 146: 1-13. https://doi.org/10.1016/j.jinorgbio.2015.02.001

Kolesnik EA, Derkho MA and Lebedeva IA, 2019. Comprehensive morphophysiological description of the immune lysosomal cationic protein of leukocytes in the early ontogeny of broiler chickens. Uchenye Zapiski Kazanskogo Universiteta. Seriya Estestvennye Nauki 161: 440-458. https://doi.org/10.26907/2542-064X.2019.3.440-458

Li Q, Wu J, Nie J, Zhang L, Hao H, Liu S, Zhao C, Zhang Q, Liu H, Nie L, Qin H, Wang M, Lu Q, Li X, Sun Q, Liu J, Zhang L, Li X, Huang W and Wang Y, 2020. The impact of mutations in SARS-CoV-2 spike on viral infectivity and antigenicity. Cell 182: 1284-1294. https://doi.org/10.1016/ j.cell.2020.07.012

Lu S, Tsai JD, Tsao TF, Liao PF and Sheu JN, 2016. Necrotizing pneumonia and acute purulent pericarditis caused by Streptococcus pneumoniae serotype 19A in a healthy 4-yearold girl after one catch-up dose of 13-valent pneumococcal conjugate vaccine. Paediatrics and International Child Health 36: 235-239. https://doi.org/10.1179/204690551 5Y.0000000022

Constantinescu GM and Constantinescu IA, 2013. The updated international veterinary anatomical and embryological nomenclatures. Journal of Veterinary Science and Animal 
Int J Vet Sci, 2022, 11(1): 104-109.

Husbandry 1: 1-3. https://doi.org/10.15744/2348-9790.1. $\underline{\mathrm{e} 201}$

Mandala VS, McKay MJ, Shcherbakov AA, Dregni AJ, Kolocouris A and Hong M, 2020. Structure and drug binding of the SARS-CoV-2 envelope protein transmembrane domain in lipid bilayers. Nature Structural and Molecular Biology 27: 1202-1208. https://doi.org/10.1038/s41594020-00536-8

Miceli MV, Newsome DA and Schriver GW, 1990. Glucose uptake, hexose monophosphate shunt activity, and oxygen consumption in cultured human retinal pigment epithelial cells. Investigative Ophthalmology and Visual Science 31: 277-283.

Morrison SJ, Uchida N and Weissman IL, 1995. The biology of hematopoietic stem cells. In: Annual Review of Cell and Developmental Biology 11: 35-71. https://doi.org/10.1146/ annurev.cb.11.110195.000343

Nowicka D, Grywalska E, Hymos A, Mielnik M and Roliński J, 2018. Possible immunomodulating effect of retinol on cytokines secretion in patients with recurrent furunculosis. Archivum Immunologiae et Therapiae Experimentalis 66: 73-79. https://doi.org/10.1007/s00005-017-0483-5

Pigarevskii VE and Mazing IUA, 1986. Method of staining for lysosomal cationic proteins in histological paraffin sections of biopsies. Arkhiv Patologii 48: 82-84.

Rechenberg DK, Galicia JC and Peters OA, 2016. Biological markers for pulpal inflammation: A systematic review. PLoS One 11: 1-24. https://doi.org/10.1371/journal.pone.0167289 Smirnova TG, Savochkina AY, Dolgushin II, Nikushkina KV and Samuseva IV, 2018. Changes in functional activity of neutrophils and monocytes isolated from the peripheral blood of women at different phases of the menstrual cycle. Bulletin of Experimental Biology and Medicine 166: 222224. https://doi.org/10.1007/s10517-018-4318-0

Tohyama Y, Tabata H and Tohyama K, 2019. Syk Plays an essential role in phagosome-lysosome fusion by facilitating actin-remodeling in complement-mediated phagocytosis. Blood 134: 2315. https://doi.org/10.1182/blood-2019 $\underline{125061}$

Tovmasyan A, Batinic-Haberle I and Benov L, 2020. Antibacterial activity of synthetic cationic iron porphyrins. Antioxidants 9: 972. https://doi.org/10.3390/antiox9100972

Ulrich S, Gottschalk C, Straubinger RK, Schwaiger K and Dörfelt $R, 2020$. Acceleration of the identification of sepsis-inducing bacteria in cultures of dog and cat blood. Journal of Small Animal Practice 61: 42-45. https://doi.org/10.1111/ jsap. 13056

Uribe-Querol E and Rosales C, 2020. Phagocytosis: Our current understanding of a universal biological process. Frontiers in Immunology 11: 1066. https://doi.org/10.3389/fimmu. $\underline{2020.01066}$

Vandendriessche S, Cambier S, Proost P and Marques PE, 2021. Complement receptors and their role in leukocyte recruitment and phagocytosis. Frontiers in Cell and Developmental Biology 9: 624025. https://doi.org/ 10.3389/fcell.2021.624025

Yousef H, Alhaij M and Sharma S, 2021. Anatomy, Skin (Integument), Epidermis. StatPearls Publishing. https://www.statpearls.com/ArticleLibrary/viewarticle/2121 $\underline{2}$ 